Témoigner

Getuigen
Témoigner. Entre histoire et mémoire

Revue pluridisciplinaire de la Fondation Auschwitz

$125 \mid 2017$

Histoire et mémoire de la persécution des homosexuel-le's par les nazis

\title{
“This Kind of Love": Descriptions of Lesbian Behaviour in Nazi Concentration Camps
}

"This Kind of Love": Descriptions du comportement lesbien dans les camps de concentration nazis

'This Kind of Love': verslagen van lesbisch gedrag in naziconcentratiekampen

\section{Claudia Schoppmann}

Translator. Elisabeth Tutschek

\section{(2) OpenEdition}

\section{Journals}

Electronic version

URL: https://journals.openedition.org/temoigner/6389

DOI: 10.4000/temoigner.6389

ISSN: 2506-6390

\section{Publisher:}

Éditions du Centre d'études et de documentation Mémoire d'Auschwitz, Éditions Kimé

\section{Printed version}

Date of publication: 1 October 2017

Number of pages: 82-90

ISBN: 978-2-930953-01-4

ISSN: 2031-4183

\section{Electronic reference}

Claudia Schoppmann, "'This Kind of Love": Descriptions of Lesbian Behaviour in Nazi Concentration Camps", Témoigner. Entre histoire et mémoire [Online], 125 | 2017, Online since 24 December 2021, connection on 03 February 2022. URL: http://journals.openedition.org/temoigner/6389 ; DOI: https:// doi.org/10.4000/temoigner.6389

This text was automatically generated on 3 February 2022.

Tous droits réservés 


\section{"This Kind of Love": Descriptions of Lesbian Behaviour in Nazi Concentration Camps}

"This Kind of Love »: Descriptions du comportement lesbien dans les camps de concentration nazis

'This Kind of Love': verslagen van lesbisch gedrag in naziconcentratiekampen

\section{Claudia Schoppmann}

Translation : Elisabeth Tutschek

\section{EDITOR'S NOTE}

This text is a translated excerpt from Schoppmann's book Nationalsozialistische Sexualpolitik und weibliche Homosexualität (Pfaffenweiler: Centaurus, 1991, revised edition 1997), p. 244-254 (from section “Zur Situation lesbischer Frauen im KZ”, p. 227-257).

Besides the confirmed but rare cases in which homosexuality was one of the reasons for detention, several examples of detainees described as lesbian can be found in memoirs of former fellow inmates. Even though the women described displayed this behaviour in camp, to conclude that they assigned themselves a lesbian identity outside the camp would not be accurate. Nor would it be correct to conclude - as is sometimes assumed that they had been arrested due to their homosexuality. All these deeply stigmatising and pejorative descriptions have one thing in common: they are external attributions.

2 As far as I can tell, testimonies by lesbian women about their imprisonment in camps do not exist. Besides, what is problematic about this genre is that, in each individual case, it cannot be determined if and to what extent events were possibly fictionalized.

One of the most detailed descriptions of lesbian conduct in the memoir genre can be found in Fania Fénelons' novel Das Mädchenorchester in Auschwitz [The Girls' Orchestra of Auschwitz], which reached high circulation and was also turned into a film. What is 
remarkable here - besides the derogatory description of lesbians - is the comparison of lesbians to prostitutes. In the chapter "Der Ball der schwarzen Dreiecke" [The Black Triangles' Ball], the Jewish chanson-singer Fania Fénelon, who had been since January 1944 ordered to play music in Auschwitz-Birkenau, writes about her encounters with the "schwarzen Winkeln" ("Black Triangles") at the camp. The scenery starts at the block of latrines, where Black Triangle Hilde reigns over all the latrines as Kapo. She is described as a "dull brute", anti-Semitic and utterly obscene: "Hilde and Inge smirk and gawk at us: drunk, their breasts exposed, fondly entangled" (Fénelon 1982, 259)1. And in all of this, Hilde's "favourites" - also women with black triangles - emulate her.

In the summer of 1944, Hilde hires Fania and the orchestra for a nocturnal "ball" at the "asocial" block. On the night in question, according to Fénelon' s description, the group of those that turned up from the "asocial" block is composed of "German prostitutes, Aryan, of course!" (Fénelon 1982, 263). ${ }^{2}$ Ninety percent of these women had "turned into homosexuals certainly because of deficiency, but also because a couple of them were enough to force this ordinance. Those who refused were battered so that they would rather join in, especially the younger ones" (Fénelon 1982, 266).

The promiscuous head of this "weird women's club" is Georgette aka George, "a real petty souteneur", whose falsetto voice makes the others giggle, while the rest of the "den's drones" rather speak with the most low-pitched voices possible to appear "more masculine" (262). There is no shortage of alcohol so that the dancing becomes more and more lascivious and soon turns into "loathsome sex-scenes, nauseating to eyes and ears" (266). An approaching guard cuts the goings-on short. ${ }^{3}$

Olga Lengyel also mentions the "Asocial' s" block and nocturnal parties. Lengyel shares Fénelon's moral condemnation of these "dance-orgies" but is more tempered. According to Lengyel, one of the instigators of those "balls" is a Polish countess, who looked and behaved like a "handsome guy around 30". By courting Lengyel, who escaped her, the countess was apparently looking for a substitute to replace her girlfriend, who had been killed in the camp. For the SS, this woman served as a source of amusement. It seems that she had arrived at the camp in men's clothes and the SS wanted to put her in the men's camp. She vehemently protested and, in return, the SS forced her to "prove" that she was a woman. Later on, they had fun watching the "gimmicks of this virago", as Lengyel refers to it, amongst the other women (Lengyel 1972, $191 \mathrm{ff}$ ).

7 Another example can be found in Krystyna Żywulska's novel Wo vorher Birken waren [There Used to be Birch Trees]. Żywulska limits herself to the derogatory description of two women in particular - both were wearing a black triangle. She provides the following observation made in the latrine-shack after her arrival at the main camp of Auschwitz in 1943:

On the planks between the holes perched a German with a black triangle - a downright masculine type. A very feminine girl with long hair was sitting on her knees. She steadily looked at her partner and then, all of a sudden, kissed her on the lips. That kiss took ages. It is quite hard to imagine something more hideous. This kind of love in that setting! (Żywulska 1980, 66)

In contrast, the second episode describes a Kapo, wearing pants and a black triangle, who tries to seduce a girl with potatoes - a delicacy at the camp. But "her leering gaze and courteous gestures" revealed the Kapo' s intentions and the girl fled (118). 


\section{Platonic Friendships vs. Same-Sex Relationships}

Fania Fénelon, Das Mädchenorchester in Auschwitz (1980)

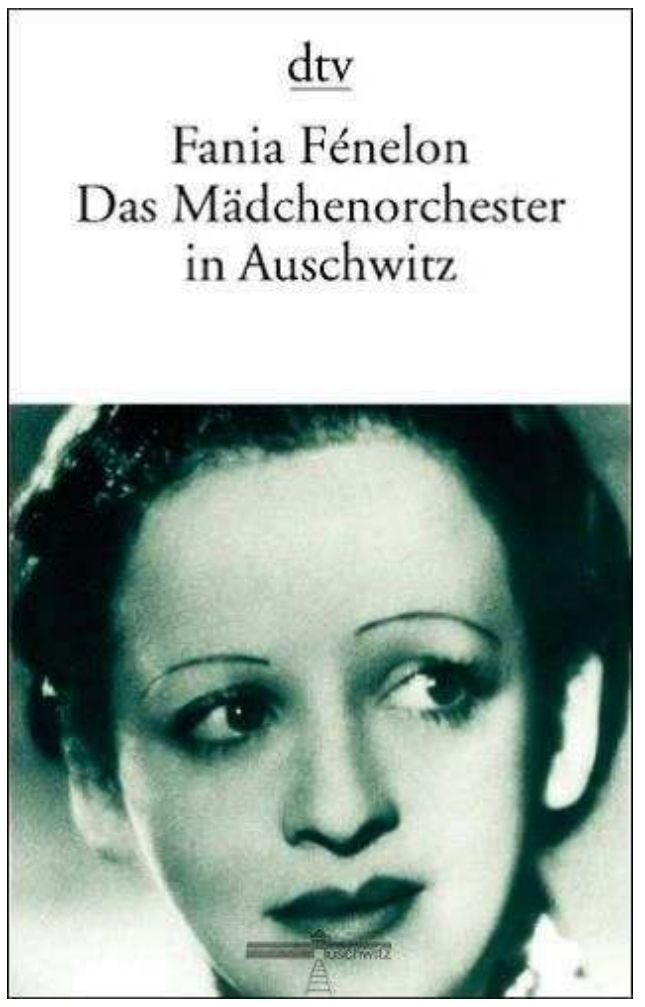

(c) D.R. 
Krystyna Zywulska, Wo Vorher Birken Waren (1979)

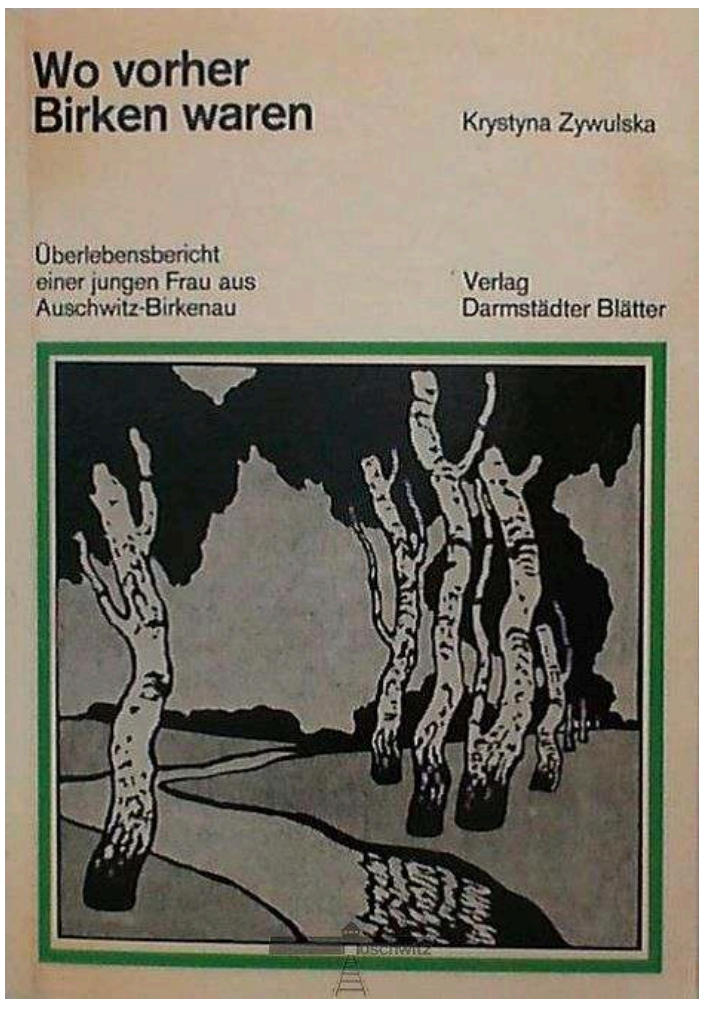

(c) D.R.

Margarete Buber - Neumann, Milena, Kafkas Freundin (1963)

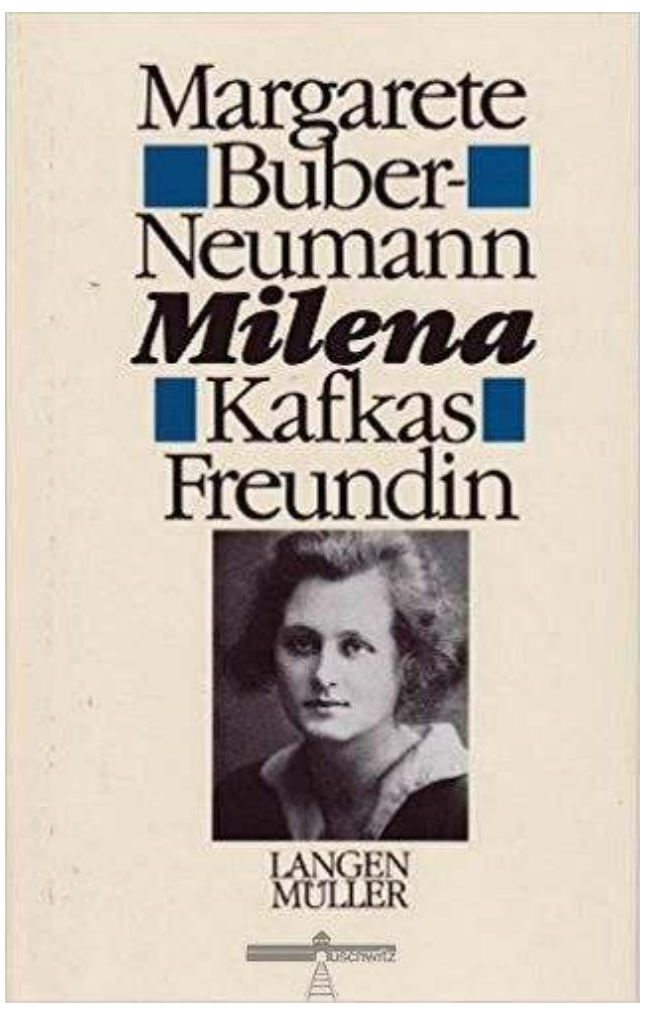

(c) D.R. 
What all these descriptions have in common - and numerous others could be added - is that the writers disapprove of individual or groups of women, whom they characterise as lesbian (see Półtawska 1993; Janz 1994). These women are clearly assigned either to the "Black Triangles" or depicted as "asocial." The equation of lesbian = asocial made by the SS was largely shared by the detainees. The denigration of female homosexuality seemed to assure their moral superiority. On the other hand, one must not neglect that the "Aryan" prisoners in Auschwitz were part of the camp' s "aristocracy" because, in principle - and in contrast to the Jewish inmates, even the "privileged ones" in the orchestra - were not bound to the gas chambers.

10 At the same time, relationships and friendships amongst the political inmates are portrayed as asexual and "pure". The more asserting the way this is expressed, the stronger, presumably, the fear of being perceived as a lesbian. Margarete BuberNeumann, who was herself a political detainee in Ravensbrück, writes in her memoir Milena, Kafkas Freundin:

Passionate friendships were as common amongst the Politicals as they were amongst the Asocials or the Criminals. Mostly, the only difference was that the relationships between the Politicals - in contrast to those between the Asocials or the Criminals - remained platonic, while the others were quite openly lesbian. [...] Asocial couples were usually composed of a masculine part and a clearly feminine part. In the Asocial' s jargon, the masculine part was called "kesser Vater" [butch]; she emphasised her broad shoulders and narrow hips, and wore her hair as short as possible. She spoke with a raspy voice and imitated the body movements of men. (Buber-Neumann 1977, 50)

11 Generally, the "openly lesbian" conduct thus remains reserved for the category of Asocial and the Criminal, while friendships amongst the Political prisoners supposedly remained pure and platonic. At the same time, each woman depended on friendships to have a chance to survive at all and Buber-Neumann's text straightforwardly recounts her close friendship with the Czech journalist and Kafka-translator Milena Jesenska. It might be for this very reason that the demarcation between "acceptable" and "objectionable" forms of friendship was required. ${ }^{5}$ In my conversations with former Ravensbrück-detainees the taboo of sexual relations amongst the Political inmates became very clear - and that there was no space for homosexuality in their selfperception. Georgia Tanewa, ${ }^{6}$ who came to Ravensbrück as a Political inmate mid-1942, put it as follows:

At the international political block where I was, nobody talked about things like that at all. In case you knew someone, who was maybe homosexual, you were diplomatic and kept silent. You could not know it, indeed you did not want to know it. You discreetly ignored it. Maybe this had to do with the puritanism of the Left at the time. Homosexuals rarely revealed themselves anyway, for obvious reasons.

I was very young at the time (19 years old) and I did not even know that homosexuality existed. It was not perceptible at our block at all, by the way. of course, there were friendships amongst women, but you really never considered that they could be homosexual. Politics always took the centre stage. Homosexuality was a strictly private issue. It was like that at our block. When you came to the so-called "asocial" blocks, it was of course different, only there was such a segregation - "asocial" and political - we actually never got together. We did not mix with those who wore a black triangle. Seen from today's point of view, that was of course unfair. As mentioned before, there were couples in the camp, usually amongst those with a black triangle. Amongst the Political inmates, there were steady friendships, but you would never know if they were homosexual. Sexual 
practices were impossible at the political block anyway - among the Asocial, probably, I do not know.

When you had been at the camp for some time and in a block, where things were somewhat orderly, which was the case for some of the blocks until, let's say, 1944, friends were being made, you definitely had a close friend. But that did not necessarily mean that there was anything erotic about it. Of course, somewhere in the unconscious, you had ideas about that, too, but you would have never let them surface. But that is what I'm saying from today's point of view.

You had the need for a close relation, for protection and tenderness, some kind of surrogate protector, what women still see in men until today. It seemed more like playing, but had a serious background. There were caresses, that is for sure, because you needed them - but personally, I would not call that homosexual relations. You need to be cautious of seeing all that through today's eyes.

After some time in detention, you needed some kind of role allocation, the way it exists for men and women in society. Women that were strong and somehow wanted to lead started to perform like men. We called Gertrud Peter, for example. I am sure that she was not homosexual in the way we understand the term today but we called her Peter. She was a Political inmate, she was accused of breach of contract because she had not shown up at work somewhere and the Gestapo at Ilmenau categorised her as a Political inmate. She was at the German political block 4 . She came to Siemens ${ }^{7}$ and we worked there together. She just had those boyish ways. She had very short hair and combed it smooth to attract attention: I look like a boy. If she was really homosexual, I do not know. We actually did have that kind of game going on, that she was in love with me, you also flirted etc., but I definitely interpreted it as nothing but playing around at the time." (In conversation with G. Tanewa on 3 March 1987)

Provided that the taboo of sexual relations amongst the Political inmates is broken at all, those kinds of relationships are presented as camp-induced and temporary, while they seemed to be overt homosexuality amongst the "Asocial". Whereas the "masculine" demeanour of a few Political inmates is regarded as something positive and did not call into question their heterosexuality, the very same thing is considered a proof of homosexuality amongst the "Asocial". The same mechanisms could be observed even more so in camps for men.. Whereas sexual relations amongst heterosexual men were prevalent and condoned, men who had been detained for their homosexuality, on the other hand, were severely judged by both the SS and other detainees (Kogon 1983, 284).

The lines of tension and conflict between detainees ran not only between the individual categories of detention, but also between the ordinary inmates and the Kapos, who were disposed of particular privileges and authority according to their specific function and position. Regardless of how an individual Kapo acted, tensions were inevitable. This was an integral part of the SS-system: to always play detainees off against each other to prevent solidarity amongst them and, above all, to prevent any resistance to the SS. ${ }^{8}$ The power imbalance between prisoners could also result in unprivileged inmates' offering to exchange sex and love in their fight for survival. Such an example of prostitution is described by Buber-Neumann:

During the penultimate camp year, when Ravensbrück started to turn chaotic, I heard about a case of lesbian procuring. He, or rather she, was named Gerda, but called herself "Gert" and provided several women with love at once. However, she did not do that out of love at all and even less so for free. She got herself paid for it. Every Saturday and Sunday the loved ones - in duty bound - supplied the spirited Gert with their rations of margarine and sausage, which were only received on weekends. (Buber-Neumann 1977, 50) 
14 Mainly due to their position, Kapos also tried to "buy" love. For example, Antoina R., a Czech Jew, reports on a German lesbian Kapo in Auschwitz, who was wearing a black triangle. The report does not disclose why she had been detained, however. The Kapo provided Antonia R. with an additional ration of bread:

Each night, the Kapo came to my bed and she always took my hand in her hand, telling me that I was her favourite, and I was so naive, I believed what she said until one day someone called my attention to it: Be careful, they can be very dangerous, too, they are homosexual, and that is something different. It was the first time in my life that I had met such people, and then the way I was told, that this was, again, for me no good. (Fürstenberg 1986 25)

15 Another case is narrated by Olga Lengyel, who gives the example of a Polish professor of physics in Auschwitz - an attractive, intelligent, and delicate woman. One of the (female) Kapos was supposedly courting her. The professor knew that she would at least escape hunger if she accepted the offer: "She must have fought a long battle with herself against this temptation, but in the end, she gave in", suspects Lengyel $(1972,191)$. After a few weeks, she would even declare that she could not live without her "wife" any more.

\section{Positive Accounts}

16 Margareta Glas-Larsson recounts another relationship of this kind in an exceptionally positive light. Glas-Larsson, an Austrian Jew, was arrested in Prague and first deported to the concentration camp Theresienstadt before she arrived in Auschwitz in May 1943. In her memoir, Ich will reden (I want to speak), she reports on her "exceptional friendship" with the German communist Aurelia Reichert-Wald ${ }^{9}$, referred to as Orli, who is described as a lesbian in other memoirs as well. ${ }^{10}$ Only from the perspective of being a persecuted Jew was it possible for Glas-Larsson to also write - even though still in a very limited way and qualified as situational - on her temporary sexual relationship with Orli Reichert, who was the camp senior at the prisoner infirmary of Auschwitz-Birkenau: ${ }^{11}$ 
Orli (Aurelia) Reichert at arrival in Auschwitz, 26 March 1942

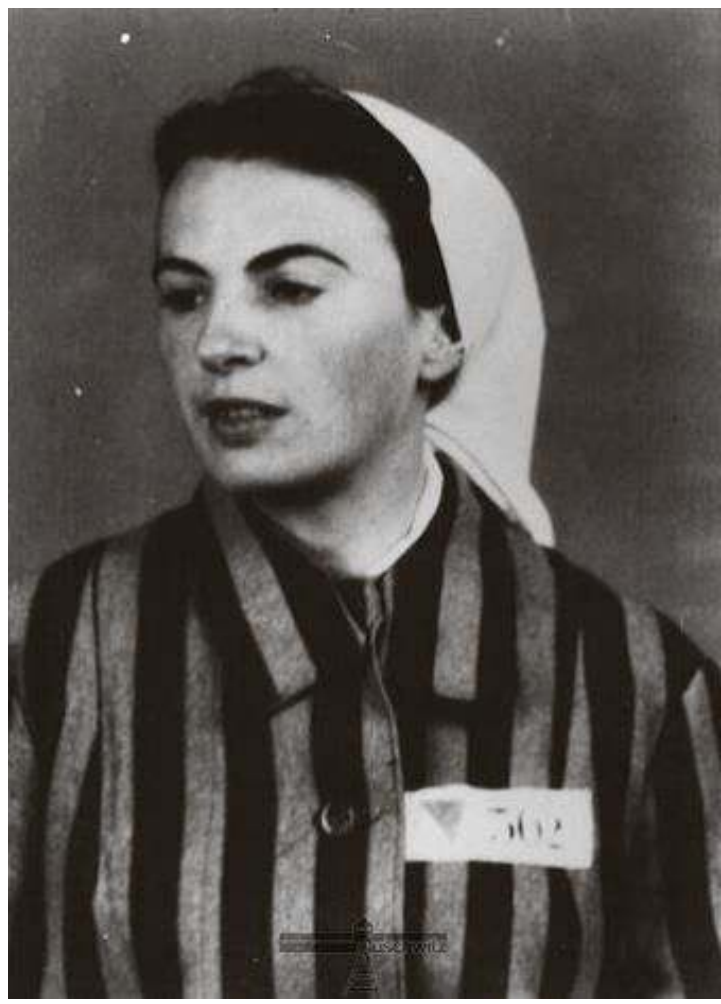

(c) D.R.

I had an exceptional friendship with Orli, for my part an immense sympathy in particular because her soul seemed so very appealing to me. She was never mean. [...] Orli was a human that I loved so dearly, no matter if woman or man. These are feelings that cannot be put into words, actually. And those feelings can only occur in such extreme situations, they do not exist in normal life, really. [...] And I believed all the way that it was my love for Orli that so strongly kept me alive. (Glas-Larsson 1981, 149)

The following quote gives a very vivid and graspable account of how the extreme conditions at the camp led to romantic relationships between women:

It is because the instinct of survival is an incredibly strong instinct. In fact, it was the most developed instinct in the camp. It was closely connected to food, of course. And an incredible need for intimacy, no matter if provided by a man or a woman. And Orli was the love of my life and I am not embarrassed about that - not at all... If you are a little bit into psychology, you understand that.

Those were dire conditions. We lacked warmth, human warmth and tenderness; things you are usually provided with in childhood already. And then, later, by the husband etc. It was really bad. And that is why you attached yourself to someone. [...] One night I asked Orli if I might stay with her. And I lay down with her. Grete Hamburger was in the room, too. That is a woman I knew from the old times in Prague. And that night the sky was deep red and I do not know if it was because the SS burned the new arrivals from Hungary and burned Jewish children or if the Sonderkommando burned so many people. Anyway, I was not unhappy, on the contrary. I was so terribly happy that night for I could stay with Orli. I also said to her over and over again: "You are the human being that I love the most, no matter if you are male or female."

Please, I mean that literally. That is what I said. We also exchanged caresses and Grete Hamburger witnessed all of it and, afterwards, she always looked at me strangely - only me. I had known her from times in liberty and all of a sudden I felt 
ashamed because she sometimes looked at me so very viciously. If it was jealousy - I do not know.

I did not mind that Grete Hamburger was in the same room. I had probably lost my inhibitions or I was too affected by all those caresses. And the sensation of feeling human warmth. I think that Orli did all of that for me out of compassion and great sympathy, and because she always said: "You are so pretty, Dolly. You have such a pretty face." And so on. I just believe she did it because I was Jewish and because I always feared for Schoschi [her husband, who was also detained in Auschwitz], and there were many different reasons for it, which are way too difficult to put in words. But it was like that. And it was the case amongst other detainees, too, that I know for sure. I was not present, but I know it, that they stuck together. And that was the right thing to do, really. (176 ff)

Similarly positive was the account from Krystyna Usarek, which she gave at a seminar at Ravensbrück Holocaust Memorial Site in the year 1993. The Polish journalist was arrested at the age of 20, in August 1944. Only when a fellow detainee working as room service "proposed" to her, did she realise that there were lesbian women in the camp, and this is what probably sharpened her perception of the following observation, which must have strongly impressed her. She reported on the relationship between a socalled camp policewoman (meaning a Kapo that had to maintain "order") and a woman that was referred to as bed-political in camp-jargon; the latter had been arrested due to her relation with a Czech man. All "Bed-political" inmates were supposed to be released from the camp at the end of February 1945, but this woman jumped off the open truck that would have guaranteed freedom only so she could stay with her lover. ${ }^{12}$

\section{The Cases of Kapo Käthe Knoll and Eleonore Baur}

19 While camp senior Orli Reichert was well respected by fellow detainees despite her sexual relations, ${ }^{13}$ other cases provoked conflict. An example for that is Käthe Knoll, a block-senior of Ravensbrück, who had lesbian relations - at least at the camp. At times, Knoll was block-senior of the so-called "cloak-and-dagger" block, which was mainly inhabited by members of occupied countries. ${ }^{14}$ From fall 1944 until the end of the war, she was camp senior of the so-called industrial complex, a sub-camp adjacent to Ravensbrück, which featured housing blocks as well as SS and armament factories, at which the inmates were forced to work.

Germaine Tillion, who was detained at the "cloak - and-dagger" block, describes Knoll as "diabolic" (Tillion 1946, 33) and the former Dutch prisoner Anne Berendsen provides a particularly detailed description of Knoll in her book Vrouwenkamp Ravensbrück (Women's camp of Ravensbrück). Berendsen writes that the latter had a "tall Russian" lady-love, who terrorised the whole block at night, and that Knoll herself "was responsible for many deaths - more than one hundred were sent to the bunker and punishment-block because of her" (Berendsen 1946, 88). ${ }^{15}$ Knoll' s lover, who actually existed, was not really Russian, though, but Dutch, as Barbara Reimann, the appointed room senior of block 5 of the industrial complex at the onset of 1945, assured me.

21 According to Reimann's descriptions, Knoll was a political detainee and a communist, ${ }^{16}$ and she attempted to prevent Reimann and others from smuggling certain women out of transports that were headed to extermination camps. They then confronted Knoll, who after all had protected her girlfriend as well. Afterwards, she arranged for those women not to "be part of transport". Knoll would not interfere in rescue operations 
ever again. After the war, Käthe Knoll was convicted of "crimes against humanity" in the GDR and spent 18 years in jail. Her love affair at the camp did not play any obvious role in this sentence however. ${ }^{17}$

Even more extreme than the above examples of relationships among Kapos and ordinary inmates was the power difference between detainees and SS-supervisors (Schwarz 1994). Inmates were without protection, at the mercy of their supervisors, and had to obey their orders without fail; otherwise, they suffered all kinds of assaults, including sexual ones. Many of the prisoners were especially stunned by the fact that other women - in their role of supervisor - would take part in the SS' crimes and that they equalled SS men in the sadistic cruelties they perpetrated. The hypothesis that women were "naturally" more peaceful than men was thereby quite painfully disproven.

In some of the reports of former detainees there are allusions to the supervisors - one of them was Irma Grese - sexually assaulting detained women (Langbein 1972, 447-449). It seems understandable that women experienced sexual coercion as particularly offending and degrading as, generally, they were (and still are) much more than men defined by their biological functions, for example, their ability for childbirth. References regarding female offenders in general (not only SS-women) are very rare, though. According to a 1950-publication of the Association of Persecutees of the Nazi Regime (VVN):

Eleonore Baur, also known as 'Sister Pia'

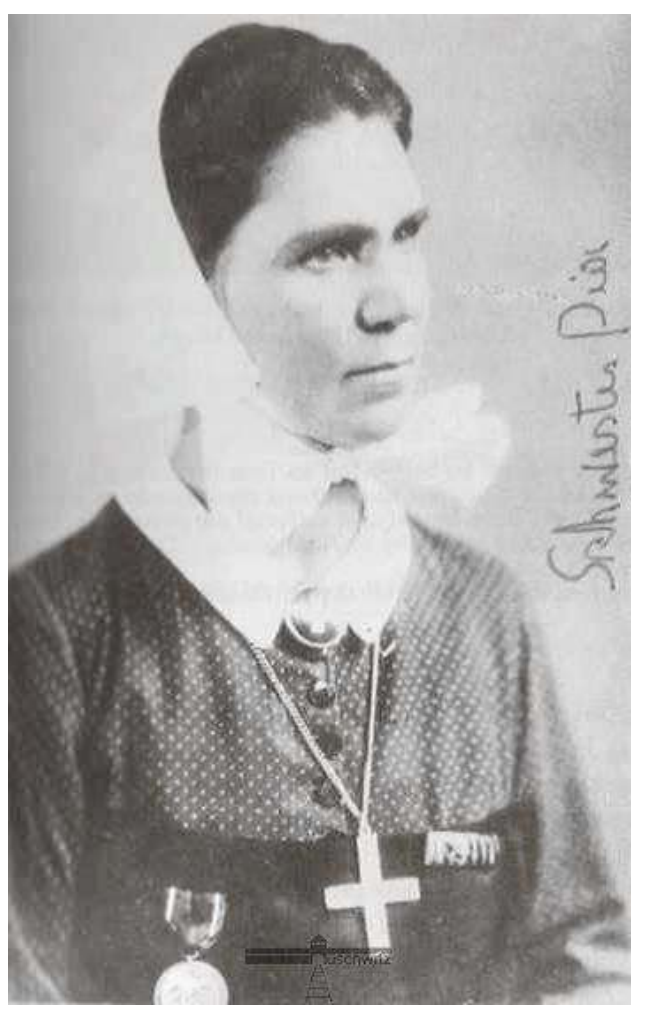

(C) D.R.

Baur, Eleonore, referred to as Sister Pia, sexually assaulted (female) detainees, abused and denunciated them, and participated in Dr. Rascher's underwater experiments. (VVN-Investigation Service Nr. 9, Sept./Oct. 1950, p. 8) 

she was part of the Hitler-putsch in 1923 and, as the only woman ever, was awarded the legendary Blood Order as well as, later on, the Golden Party badge. After 1933, Eleonore Baur (1885-1981) had free access to the camp of Dachau, forced detainees to work for her, and participated in SS doctor Rascher's murderous experiments that included 200 inmates. Although other sources mentioned sexual assault, too - but exclusively against men, among them also a pink - triangle-prisoner (Föster 1982) - there was not enough evidence to convict her of sexual abuse during her post-war trial (Holzhaider 1994).

\section{BIBLIOGRAPHY}

Berendsen, Anne, Vrouwenkamp Ravensbrück, Utrecht: De Haan, 1946.

Buber-Neumann, Margarete, Milena, Kafkas Freundin, München: Langen Müller, 1977.

Eschebach, Insa, 'Das Stigma des Asozialen. Drei Urteile der DDR-Justiz gegen ehemalige Funktionshäftlinge des Frauenkonzentrationslagers Ravensbrück', Beiträge zur Geschichte der nationalsozialistischen Verfolgung in Norddeutschland 4, 1998, 69-81.

Fénelon, Fania, Das Mädchenorchester in Auschwitz, München: Deutscher Taschenbuch Verlag, 1982.

Föster, Michael, 'Schwester Pia und die Sklaven', in: Rainer Schilling (ed.), München von Hinten. Berlin: Bruno Gmünder Verlag, 1982, 51-52.

Fürstenberg, Doris (ed.), Jeden Moment war dieser Tod. Interviews mit jüdischen Frauen, die Auschwitz überlebten, Düsseldorf: Schwann, 1986.

Glas-Larsson, Margarete, Ich will reden. Tragik und Banalität des Überlebens in Theresienstadt und Auschwitz, Gerhard Botz (ed.), Vienna: Molden, 1981.

Holzhaider, Hanz, 'Schwester Pia. Nutznießerin zwischen Opfern und Tätern', Dachauer Hefte 10(10), 1994, 101-114.

Janz, Ulrike, 'Lesben / lesbische Verhalten in nationalsozialistischen Konzentrationslagern Zeugnisse überlebender Frauen und was sie uns (nicht) sagen', in Madeleine Marti, Angelika Schneider, Irena Sgier \& Anita Wymann, Querfeldein. Beiträge zur Lesbenforschung, Bern: eFeFVerlag, 1994, 114-118.

Kogon, Eugen, Der SS-Staat. Das System der deutschen Konzentrationslager, München: Heyne, 14th edition 1983.

Langbein, Herrmann, Menschen in Auschwitz, Vienna: Europa Verlag, 1972.

Lengyel, Olga, Five Chimneys: A Woman Survivor's True Story of Auschwitz, London, New York: Mayflower, 1972.

Müller, Wolfgang, Auschwitz. Geschichte und Wirklichkeit des Vernichtungslagers, Reinbek bei Hamburg: Rowohlt, 1980.

Półtawska, Wanda, Und ich fürchte meine Träume, Abensberg: Maria Aktuell Verlag, 1993. 
Sofsky, Wolfgang, Die Ordnung des Terrors: Das Konzentrationslager, Frankfurt am Main: S. Fischer Verlag, 1993.

Schwarz, Gudrun, 'SS-Aufseherinnen in Nationalsozialistischen Konzentrationslagern (1933-1945)', Dachauer Hefte 10(10), 1994, 32-49.

Steger, Bernd \& Günter Thiele, Der dunkle Schatten. Leben mit Auschwitz. Erinnerungen an Orli Reichert-Wald, Marburg: SP-Verlag, 1989.

Tillion, Germaine, Ravensbrück, Neuchatel: Cahiers du Rhône, 1946.

Żywulska, Krystyna, Wo vorher Birken waren, München: Kindler, 1980.

\section{Further references}

Eschebach, Insa, 'Homophobie, Devianz und weibliche Homosexualität im Konzentrationslager Ravensbrück', in Insa Eschebach (ed.), Homophobie und Devianz. Weibliche und männliche Homosexualität im Nationalsozialismus, Berlin: Metropol Verlag, 2012, 65-78.

Hájková, Anna, 'Das verborgene Leben der Eleonore Behar', 27 January 2017, http://www.lsbttiqbw.de/2017/01/27/das-verborgene-leben-der-eleonore-behar/ (accessed 20 July 2017).

Marhoefer, Laurie, 'Lesbianism, Transvestism, and the Nazi State: A Microhistory of a Gestapo Investigation, 1939-1943', American Historical Review 121, 2016, 1167-1195.

Schoppmann, Claudia, Days of Masquerade: Life Stories of Lesbians during the Third Reich, New York: Columbia University Press, 1996.

Schoppmann, Claudia, 'Elsa Conrad, Margarete Rosenberg, Mary Pünjer, Henny Schermann: Vier Porträts', in Insa Eschebach (ed.), Homophobie und Devianz. Weibliche und männliche Homosexualität im Nationalsozialismus, Berlin: Metropol Verlag, 2012, 97-111.

Schoppmann, Claudia, 'Zwischen strafrechtlicher Verfolgung und gesellschaftlicher Ächtung: Lesbische Frauen im "Dritten Reich", in Insa Eschebach (ed.), Homophobie und Devianz. Weibliche und männliche Homosexualität im Nationalsozialismus, Berlin: Metropol Verlag, 2012, 35-51.

Schwartz, Michael (ed.), Homosexuelle im Nationalsozialismus. Neue Forschungsperspektiven zu Lebenssituationen von lesbischen, schwulen, bi-, trans- und intersexuellen Menschen 1933 bis 1945, München: Oldenbourg, 2014.

\section{NOTES}

1. All translations from German sources are Elisabeth Tutschek' s.

2. In fact this category comprised in Auschwitz i.a. both prostitutes (mostly of German nationality), and more than 20,000 Sinti and Roma that were held in a "family camp". See Müller $1980,62$.

3. A film was produced based on Fénelon's book. The scenario Spiel um Zeit (Playing for Time, Frankfurt am Main, 1981) by Arthur Miller does not go into the plot of the above-mentioned ball and the depiction of those wearing a black triangle as lesbian prostitutes. A lesbian relationship between Tschaikowska, the violent Kapo at the music-block, and one of the block seniors (Fénelon 1982, 104) is slightly hinted at. Yet, a clearly positive depiction is given of the budding amorousness between Charlotte and Michou, two young women in the orchestra. Such a positive description of a tender relationship between two women does not exist in Fénelon's book at all. 
4. The author's disgust only concerns the lesbian aspect of this scene; in contrast, friendships and romantic relations between male and female detainees - also Żywulska's own ones - are depicted in very sympathetic ways (see pages $213 \mathrm{ff}$ ).

5. The denegation of (camp-)homosexuality often also involved the denunciation of "masculine" appearance or behaviour. The transformation of look was related to the camp (e.g. forced shaving of hair) and affected each detainee for the time being. In a situation in which many women feared for their femininity, the "masculine" appearance of others might have seemed even more drastic for their own identity.

6. Tanewa, a native of Bulgaria, was living in Poland when the war broke out, came to Germany for forced labour, and joined in resistance as a pamphlet messenger, whereupon she was detained. She was in Ravensbrück from mid-1942 until the end of the war. See Mario Offenberg's film Alptraum als Lebenslauf. Das Zeugnis der Georgia T. (1982).

7. Siemens \& Halske built an armaments factory in immediate camp proximity, at which, besides civilian workers, 2500 camp detainees had to work.

8. About the social structure at the camp see Sofsky 1993, 115-190.

9. Aurelia Reichert-Wald, born in Trier in 1914, German communist, was detained in 1936 and, after serving a sentence of four and a half years in jail, came first to the camp of Ravensbrück and, in 1942, to Auschwitz-Birkenau with the first transport. At the end of the year 1943, she became camp senior of the prisoners' infirmary. Physically and psychologically broken by her time in detention, she died on January 1, 1962. See Steger \& Thiele 1989.

10. According to Lengyel (1972, 191ff), Orli Reichert regularly participated in nocturnal "dance soirées" organized at the "asocial" block.

11. Gerhard Botz, historian and editor of Glas-Larsson' s book, at this point quite rightly notes: "Had Margareta Glas-Larsson got into the oppressive machinery of the SS-state as a so-called Asocial, a vagabond, a prostitute, a homosexual, someone work-shy, etc. or as an apolitical criminal, she could not have chosen to make the story of her life public today, using it as a way out of her traumatic state. And even if, she would have aimed to bend her life story and make it completely political. The history of inhumane apolitical prosecution during German fascism is not considered historically worthy." (Glas-Larsson 1981, 64)

12. I want to thank Christa Schulz, Ravensbrück Memorial Site, for the information. The example also shows the importance of interviews with witnesses, especially regarding such taboo-issues.

13. See Langbein 1972, 247ff. Langbein reports that he had "never heard or read anything negative" about Orli Reichert. Many former inmates stressed "that despite her high rank in the camp, she never forgot that National Socialism was the common enemy of all detainees, and that she helped wherever she could".

14. This block was established in 1942 according to the Night and Fog directive of 4 February 1942 concerning the occupied countries. The order signed by Keitel, head of the OKW (Supreme Command of the Armed Forces), determined that crimes against the Reich or the occupying power always were to be punished by death penalty. Relatives did not get any information as to the fate or the whereabouts of detainees.

15. The eerie image of Knoll drawn by Berendsen is put into question by the author' s report, which is in part factually wrong and, besides, peppered with prejudices, assertions, and generalizations. She pulls all the prisoner groups to pieces - apart from the Dutch. She refers to German detainees as "all lesbian" (85).

16. This contradicts the information given by the Attorney General, see next annotation.

17. Written notice of the Attorney General, GDR, 20 June 1988: “On 5 July 1948, the Regional Court Dresden [...] convicted the nurse Katharina Henriette Sopie Angeler, née Knoll, of crimes against humanity to 18 years of jail. The sentence was based on evidence that the accused had denounced fellow detainees to camp administration at the concentration camp of Ravensbrück and that she had also abused some of them on various occasions. Furthermore, since Katharina Knoll (she got 
married to Hans Angeler in August 1945) held the function of camp senior, in the spring of 1945, she assisted in the selection of diseased detainees that were subsequently gassed. Eventually, according to her own plea, she became part of the so-called camp police at the beginning of March 1945 and wore their red armband. As far as I can tell, questions concerning homosexuality were not debated during the trial. For the rest, the convict had given birth to a boy in each of the years 1932, 1933, and 1935, and to a girl in 1937. Each of the children grew up with its respective father. During the Dresden trial, Mrs. Angeler explained that the reason why she had been taken to the concentration camp in the first place was alleged racial defilement. According to her recollection, the preventive custody file said 'sabotaging the Führer's integration process and nation-destructive conduct'." For more information about the trial against Knoll, who died in 1952 in Waldheim prison (East Germany) at the age of 47, see Eschebach 1998, 69-81.

\section{ABSTRACTS}

Claudia Schoppmann propose une synthèse des recherches sur les femmes lesbiennes sous la botte nazie. S'appuyant sur des témoignages de survivantes de la déportation, elle montre la vivacité d'une sous-culture lesbienne à l'intérieur de l'univers concentrationnaire, mais aussi les tensions inhérentes à un univers fermé et monosexué qui, pour différentes raisons, avait tendance à mettre sur la touche les femmes homosexuelles. Cet article nous offre ainsi une plongée dans un univers qui n'est pas exempt de violences, notamment sexuelles.

Het artikel van Claudia Schoppmann biedt een overzicht van het onderzoek naar het lot van lesbische vrouwen onder de nazidictatuur. Aan de hand van getuigenissen van overlevenden schetste ze de levendige lesbische subcultuur in de concentratiekampen, maar ook de spanningen die ontstaan binnen een gesloten wereld waarin homoseksuele vrouwen om verschillende redenen geïsoleerd leefden. Vele vrouwen bleven met name niet gespaard van seksueel geweld. 